\title{
Colorimetric Micro-determination of Titanium Dioxide in Foods
}

\author{
Takashi Hamano*, Yukimasa Mitsuhashi*, Nobumi AoKI*, \\ Susumu Yamamoto*, Sumiko TsujI**, Yoshio Iтo** \\ and Yoshikiyo OJI ${ }^{* * *}$ \\ * Public Health Research Institute of Kobe City, \\ Minatozimanaka-machi, Kobe 650 \\ ** National Institute of Hygienic Science, Osaka Branch, \\ Hoenzaka, Osaka 540 \\ *** Faculty of Agriculture, Kobe University, \\ Rokkodai, Kobe 658
}

\begin{abstract}
A colorimetric procedure for the micro-determination of titanium dioxide $\left(\mathrm{TiO}_{2}\right)$ has been developed. The method incorporates wet-ashing and color development using diantipyrylmethane. The yellow-to-orange color is quite stable. Interference from $\mathrm{Fe}^{3+}$ ion could be removed in the presence of ascorbic acid. More than $90 \%$ of $\mathrm{TiO}_{2}$ spiked at the 10 and 100 $\mu \mathrm{g} / \mathrm{g}$ levels were recvered from cheese and white chocolate. The proposed method is rapid, simple and accurate. The minimum level for determination of $\mathrm{TiO}_{2}$ was $5 \mu \mathrm{g} / \mathrm{g}$ when $2 \mathrm{~g}$ of sar'ple was assayed.
\end{abstract}

Titanium dioxide $\left(\mathrm{TiO}_{2}\right)$ is frequently used as a whitener in cheese, chocolate and chewing gum. Current regulations of The Ministry of Health and Welfare of Japan have no limits for the use of $\mathrm{TiO}_{2}$ in foods mentioned above. The use of the material and the absence of legal limits for its use initiated the work on a quantitative method to meet any regulatory demands.

A quantitative method was developed which incorporated ashing of the sample, dissolution of the ash in sulfuric acid to a known amount of volume, and development of yellow color with hydrogen peroxide ${ }^{1)}$. The reaction is, however, of very low sensitivity, and is subject to interference from other ions ${ }^{2}$. We therefore have sought for an alternative spectrophotometric method.

In the literature, titanium in minerals was determined spectrophotometrically by using organic reagents ${ }^{324) 5 \text { ). }}$ However, these methods involve many steps for color development. Atomic absorption spectrometry also is an unfavorable method because of the difficulty in atomization of titanium. Although a little less sensitive than other organic reagents ${ }^{3345)}$, diantipyrylmethane is relatively specific for titanium and less subject to interference from other metallic ions ${ }^{6}$. In the present work, we intended to make use of diantipyrylmethane for the quantitation of $\mathrm{TiO}_{2}$ in foods.

\section{Materials and Methods}

\section{Food samples}

Processed cheese, chocolate and chewing gum were purchased from local market in Kobe City.

\section{Reagents and apparatus}

Reagent solution for color development reaction was prepared by dissolving $2.5 \mathrm{~g}$ of diantipiyrylmethane (analytical grade, Wako Pure Chemicals) in $100 \mathrm{ml}$ of $2.5 \mathrm{~N} \mathrm{HCl}$. Titanium dioxide $\left(\mathrm{TiO}_{2}\right)$ of high purity $3-\mathrm{N}$ grade was obtained from Mitsuwa Pure Chemicals. All other reagents were of analytical grade.

Hitachi Model 200-10 spectrophotometer with $1-\mathrm{cm}$ cells was used for measurements. 


\section{Preparation of standard solution}

Accurately weigh $50 \mathrm{mg}$ of $\mathrm{TiO}_{2}$ and transfer to $500 \mathrm{ml}$ tall beaker. Add $10 \mathrm{~g}$ of ammonium sulfate and $10 \mathrm{~m} l$ of concentrated $\mathrm{H}_{2} \mathrm{SO}_{4}$. Cover with watch glass, and then heat the contents on hot plate to dissolve. Cool, and cautiously add $100 \mathrm{ml}$ of distilled water with stirring. Cool, transfer the solution to $500 \mathrm{~m} l$ volumetric flask, and dilute to the mark with distilled water. The concentration of titanium of this solution is $0.1 \mathrm{mg} / \mathrm{m} l$ as $\mathrm{TiO}_{2}$. Dilute this solution with distilled water to make a series of working standard solutions $(0.2 \sim 10 \mu \mathrm{g} / \mathrm{m} l$ as $\mathrm{TiO}_{2}$ ).

\section{Preparation of sample digests}

Take $0.5 \sim 2 \mathrm{~g}$ of food sample, depending on whether food is rich in sugar or not, into $300 / \mathrm{ml} \mathrm{Kjeldahl} \mathrm{flask.} \mathrm{Add} 10 \mathrm{ml}$ of water if sample is solid. Add $5 \mathrm{~g}$ of ammonium sulfate, $10 \mathrm{~m} l$ of concentrated $\mathrm{H}_{2} \mathrm{SO}_{4}$ and $5 \mathrm{~m} l$ of $\mathrm{HClO}_{4}$, then bring the contents to boil. If the digest fails to darken on prolonged boiling during destruction of organic matter, cool and add a few more drops of $\mathrm{HClO}_{4}$. Boil gently until evolution of dense white fumes of $\mathrm{HClO}_{4}$ ceases. Cool the flask and contents, add $10 \mathrm{ml}$ of distilled water, transfer the solution quantitatively to a $50 \mathrm{~m} l$ volumetric flask with an aid of distilled water, and finally dilute to the mark. The resulting $50 \mathrm{~m} l$ of digest solution, of which $\mathrm{H}_{2} \mathrm{SO}_{4}$ concentration did not exceed $7.2 \mathrm{~N}$ in maximum, should be colorless and free from suspended solids. Prepare a reagent blank solution at the same time from the same volumes of acid used in sample digestion.

\section{Assay of titanium dioxide}

Take $5 \mathrm{~m} l$ of sample digest solution containing not more than $50 \mu \mathrm{g}$ of $\mathrm{TiO}_{2}$ into a $25 \mathrm{ml}$ test-tube. Add $1 \mathrm{ml}$ of $5 \%(\mathrm{w} / \mathrm{v})$ ascorbic acid solution and $4 \mathrm{~m} l$ of reagent solution in this order, and mix well. Allow the mixture to stand for $10 \mathrm{~min}$ at ambient temperature. Measure the absorbance of this solution at a wavelength of $390 \mathrm{~nm}$ against a blank solution in which $2.5 \mathrm{~N} \mathrm{HCl}$ replaced the reagent solusion. Calculate the $\mathrm{TiO}_{2}$ in food sample from a calibration curve.

\section{Results and Discussion}

Effect of the amounts of reagent and reaction time

Titanium is well known to react with diantipyrylmethane to form yellow-to-orange color complex ${ }^{6}$. The spectra of complex show a well defined maximum at $390 \mathrm{~nm}$. Hence, the measurements of absorbance were done at $390 \mathrm{~nm}$ in the subsequent experiments. No detailed information on the optimum amount of diantipyrylmethane is available. We therefore examined the effect of the amount of diantipyrylmethane on the reaction. If we assume that $3 \mu \mathrm{mol}$ of diantipyrylmethane reacts with $1 \mu \mathrm{mol}$ of titanium, then $146 \mu \mathrm{g}$ of this reagent are sufficient for $10 \mu \mathrm{g}$ of titanium (as $\mathrm{TiO}_{2}$ ). However, the amount of diantipyrylmethane needed for optimum reaction under our analytical conditions was largely in excess of the theoretical value, as is obvious from Fig. 1. This is simply ascribed to the faster kinetics of the reaction with large amounts of reagent. Taking into account the cost of reagent and speed of analysis, $4 \mathrm{ml}$ of diantipyrylmethane reagent $(25 \mathrm{mg} / \mathrm{ml})$ was adopted for routine analysis.

JAFFERY and GREGORY ${ }^{6)}$ reported that more

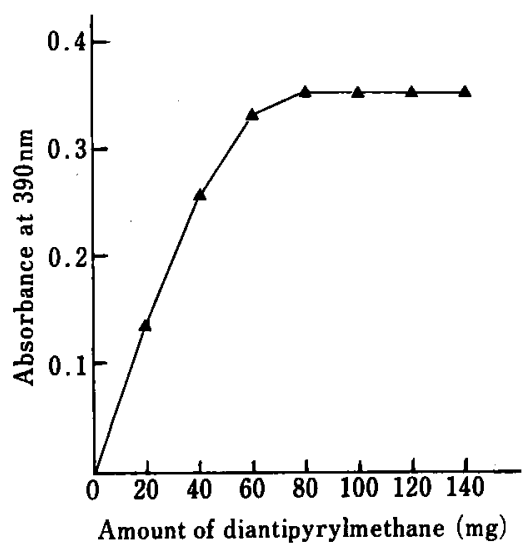

Fig. 1 Effect of amount of diantypyrylmethane on the color development

Ten $\mu \mathrm{g}$ of titanium dioxide was reacted with varying amounts of diantipyrylmethane for $10 \mathrm{~min}$. 
than $2 \mathrm{~h}$ was required for maximum color development. However, under our analytical conditions $10 \mathrm{~min}$ was sufficient (see Fig. 2). This discrepancy can be explained by the fact that the amount of reagent used in this study was 4 times higher than that in the literature ${ }^{6}$. Effect of acidity

It is obvious from the literature ${ }^{6)}$ that concentration of $\mathrm{HCl}$ in the reaction mixture is a critical factor for the optimum reaction of titanium with diantipyrylmethane. Hence, the optimum concentration of $\mathrm{HCl}$ was examined. The maximum color development was obtained at $\mathrm{HCl}$ concentration of $0.7-1.3 \mathrm{~N}$ under our assay conditions. Accordingly, we made the reagent solusion by dissolving diantipyrylmethane in $2.5 \mathrm{~N} \mathrm{HCl}$. The use of $4 \mathrm{ml}$ of this reagent gave $\mathrm{HCl}$ concentration of $1 \mathrm{~N}$ in $10 \mathrm{ml}$ of the reaction mixture. Concerning the effect of other mineral acids on the reaction, no detailed evaluation has been made. In this study, effect of $\mathrm{H}_{2} \mathrm{SO}_{4}$ concentation on the reaction was examined within 1-6 N. At these $\mathrm{H}_{2} \mathrm{SO}_{4}$ concentrations, the color intensity did not alter in response to change in acidity. This is beneficial to our assay system, in which the digest solution with high acidity was directly subjected to assay of titanium.

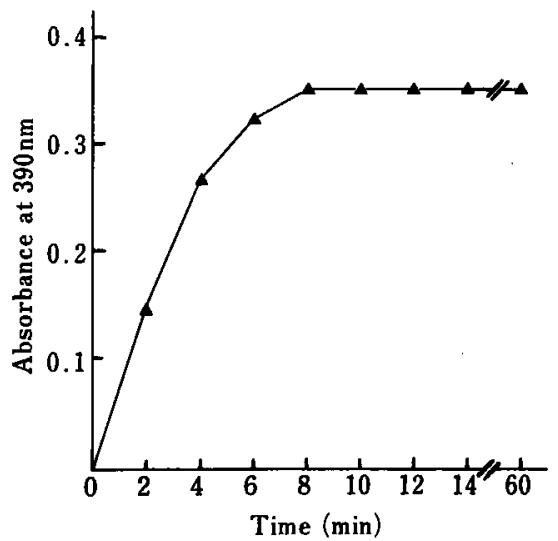

Fig. 2 Effect of reaction time on color development

Ten $\mu \mathrm{g}$ of titanium dioxide was reacted with $100 \mathrm{mg}$ of diantypyrylmethane for indicated time.

\section{Digestion of food sample}

Much has been written on the relative merits of dry and wet ashing for the determination of metal ions ${ }^{778)}$. We prefer wet ashing for the determination of $\mathrm{TiO}_{2}$, because it normally requires less time and the risk of the occurrence of losses by volatilization is eliminated. When white chocolate spiked with $100 \mu \mathrm{g} / \mathrm{g}$ of $\mathrm{TiO}_{2}$ was digested using $\mathrm{H}_{2} \mathrm{SO}_{4}$ alone, the value obtained by the proposed method was only about $60 \%$ of the spiked level. In contrast, wet ashing with $\mathrm{H}_{2} \mathrm{SO}_{4}$ in the presence of ammonium sulfate $(5 \mathrm{~g})$ gave satisfactory results $(99.5 \mu \mathrm{g} / \mathrm{g})$. From these observations, it is obvious that the presence of ammonium sulfate is essential for the determination of $\mathrm{TiO}_{2}$. At present, we have no reasonable explanation about the effect of ammonium sulfate.

Perchloric acid was used as an oxidant rather than $\mathrm{HNO}_{3}$ for two reasons. First, trace amounts of $\mathrm{HClO}_{4}$, if retained in the digest solution, did not affect the reaction of titanium with diantipyrylmethane. Secondly, the complete destruction of organic matter required much less time when $\mathrm{HClO}_{4}$ was used rather than $\mathrm{HNO}_{3}$ was used in the presence of $\mathrm{H}_{2} \mathrm{SO}_{4}$.

\section{Effect of diverse ions}

Titanium $\left(2 \mu \mathrm{g} / \mathrm{m} l\right.$ as $\left.\mathrm{TiO}_{2}\right)$ was determined in the presence of a number of diverse ions (Table 1). Moderate amounts of various

Table 1 Effect of diverse ions on the determination of $2 \mu \mathrm{g} / \mathrm{ml}$ of titanium dioxide

\begin{tabular}{llc}
\hline \hline Diverse ion & $\begin{array}{c}\text { Added as } \\
(\mu \mathrm{g} / \mathrm{m} l)\end{array}$ & $\begin{array}{c}\text { Absorbance at } \\
390 \mathrm{~nm}\end{array}$ \\
\hline None & & 0.42 \\
$\mathrm{Ca}^{2+}$ & $\mathrm{CaCl}_{2}(200)$ & 0.42 \\
$\mathrm{Mg}^{2+}$ & $\mathrm{MgCl}_{2}(20)$ & 0.42 \\
$\mathrm{~Pb}^{2+}$ & $\mathrm{PbCl}_{3}(20)$ & 0.42 \\
$\mathrm{Fe}^{3+}$ & $\mathrm{FeCl}_{3}(2)$ & $0.49(0.42)^{*}$ \\
$\mathrm{Zn}^{2+}$ & $\mathrm{ZnSO}_{4}(20)$ & 0.42 \\
$\mathrm{Cu}^{2+}$ & $\mathrm{CuSO}_{4}(20)$ & 0.42 \\
$\mathrm{Al}^{3+}$ & $\mathrm{AlCl}_{3}(20)$ & 0.42 \\
$\mathrm{PO}_{4}{ }^{3-}$ & $\mathrm{H}_{3} \mathrm{PO}_{4}(200)$ & 0.42 \\
\hline
\end{tabular}

* Ascorbic acid was added. 
metal ions and anions commonly present in foods were tolerated. However, $\mathrm{Fe}^{3+}(2 \mu \mathrm{g} / \mathrm{m} l)$ interfered in the proposed method. Interference from $\mathrm{Fe}^{3+}$ was avoided by prior reduction to lower valency states with ascorbic acid.

\section{Calibration curve}

The calibration curve prepared according to the present method is linear. Beer's law is obeyed for titanium (as $\mathrm{TiO}_{2}$ ) in the range $0.2 \sim 10 \mu \mathrm{g} / \mathrm{g}$. The relation between absorbance (A) at $390 \mathrm{~nm}$ and the concentration (C) of $\mathrm{TiO}_{2}$ was obtained by the least-squares method :

$$
\mathrm{C}=4.77 \mathrm{~A}+0.02
$$

Therefore, the present method had a minimum quantitaive level of about $5 \mu \mathrm{g} / \mathrm{g}$ when $2 \mathrm{~g}$ of sample was digested and diluted to $50 \mathrm{ml}$.

\section{Recovery test}

Processed cheese and chocolate, which are known and verified to be free of $\mathrm{TiO}_{2}$, were selected for the preparation of sample to contain 10 , and $100 \mu \mathrm{g} \mathrm{TiO}_{2}$. Samples containing $\mathrm{TiO}_{2}$ were prepared by making a slurry with hot water $\left(60^{\circ} \mathrm{C}\right)$, adding known amounts of $\mathrm{TiO}_{2}$, and blending in a Waring blender. The samples were then heated on a $60^{\circ} \mathrm{C}$ water bath and periodically mixed by stirring to release the added water and to return the samples to their approximate original weight and consistency. The samples were then analyzed according to the method described in Materials and Methods. Recovery of $\mathrm{TiO}_{2}$ from 2 kinds of foods were satisfactory, results being $92.1 \sim 94.9 \%$ for spiking at 10 $\mu \mathrm{g} / \mathrm{g}$ and $97.4 \sim 99.8 \%$ for spiking at $100 \mu \mathrm{g} / \mathrm{g}$ (see Table 2).

\section{foods}

Application to commercially available

Table 3 shows a comparison of results obtained for the determination of $\mathrm{TiO}_{2}$ in several commercially available foods using the proposed method and hydrogen peroxide method $^{1)}$. The latter method gave somewhat lower values compared to those obtained by the proposed method, especially for food sample low in $\mathrm{TiO}_{2}$ contents. This may be attributed to low sensitivity and/or complex procedure for sample treatment in the hydrogen peroxide
Table 2 Results of recovery study of titanium dioxide in cheese and chocolate

\begin{tabular}{ccc}
\hline Food & $\begin{array}{c}\text { Amount added } \\
(\mu \mathrm{g} / \mathrm{g})\end{array}$ & $\begin{array}{c}\text { Recovery* } \\
(\%)\end{array}$ \\
\hline Processed cheese A & 10 & $92.1 \pm 2.3$ \\
Processed cheese B & 100 & $97.4 \pm 2.4$ \\
White chocolate A & 10 & $94.9 \pm 3.1$ \\
& 100 & $99.3 \pm 2.6$ \\
White chocolate B & 10 & $93.8 \pm 1.8$ \\
& 100 & $99.5 \pm 2.8$ \\
\end{tabular}

* Results represent mean value and standard deviation of triplicate determinations.

Table 3 Comparison of methods on the determination of titanium dioxide in several kinds of foods

\begin{tabular}{lcc}
\hline \hline \multirow{2}{*}{ Food } & \multicolumn{2}{c}{ Titanium dioxide content $(\mu \mathrm{g} / \mathrm{g})$} \\
\cline { 2 - 3 } & $\begin{array}{c}\text { Proposed } \\
\text { method* }\end{array}$ & $\begin{array}{c}\text { Hydrogen } \\
\text { peroxide } \\
\text { method }\end{array}$ \\
\hline $\begin{array}{l}\text { Processed cheese A } \\
\text { Processed cheese B }\end{array}$ & $\begin{array}{c}\text { N.D. } .^{* *} \\
\text { White chocolate }\end{array}$ & $\begin{array}{l}\text { N.D. }{ }^{* *} \\
\text { N.D. }\end{array}$ \\
$\begin{array}{l}\text { Marble chocolate } \\
\text { (brown) }\end{array}$ & $15 \pm 0.4$ & N.D. \\
$\begin{array}{l}\text { Marble chocolate } \\
\text { (yellow) }\end{array}$ & $50 \pm 2.1$ & 35 \\
Chewing gum & N.D. & N.D. \\
\hline
\end{tabular}

* Results represent mean value and standard deviation of triplicate determinations.

** N.D.: Not detected.

method.

In summary, the proposed method is rapid and reliable. Further, the sensitivity of this method is more than 20 times higher than that of hydrogen peroxide method. Ten to 20 samples can be assayed routinely for $\mathrm{TiO}_{2}$ in $5 \sim 6 \mathrm{~h}$ as opposed to 1 or 2 days when hydrogen peroxide method is used.

\section{References}

1) Leone, J.L. : J. Assoc. Off. Anal. Chem., 56, 535 (1973). 
2) Merwin, H.E. : Am. J. Sci., 28, 119 (1909).

3) IsHII, H. : Bunseki Kagaku, 21, 665 (1972).

4) Yoe, J.H.: Anal. Chim. Acta, 6, 450 (1952).

5) Agrawal, Y.K. and John, K.T. : Analyst, 110, 57 (1985).

6) JefFery, P.G. and Gregory, G.R.E.C. : Analyst, 90, 177 (1965).

7) Hoover, W.L., Reagor, J.C. and Garner, J.C. : J. Assoc. Off. Anal. Chem., 52, 708 (1969).

8) Roschnik, R.K. : Analyst, 98, 596 (1973).

(Received May. 30, 1989)
食品中の二酸化チタンの微量比色定量法

浜野 孝 $^{*}$ ・三ッ橋幸正 ${ }^{*}$ ・青木伸實 ${ }^{*}$ ・山本 進*。 辻 澄子**

* 神戸市環境保健研究所 （开650 神戸市中央区港島中町 4-6）

**国立衛生試験所大阪支所 （干540 大阪市中央区法円坂町 1-1）

*** 神戸大学農学部

（T658 神戸市灘区六甲台町 1-1）

食品中の二酸化チタンの微量定量法について検討した 試料 $(0.5 \sim 2 \mathrm{~g})$ を硫酸アンモニウムの存在下で濃硫酸 と過塩素酸で湿式分解し, 冷後蒸留水で $50 \mathrm{ml}$ に定容 した.これの $5 \mathrm{ml}$ を比色管により， $1 \mathrm{ml}$ の $10 \%$ アス

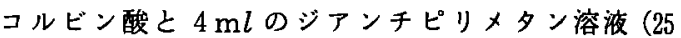
$\mathrm{mg} / \mathrm{m} l 2.5 \mathrm{~N}$ 塩酸) を加え，30 分室温で放置後 390 $\mathrm{nm}$ で吸光度を測定する．二酸化チタンの標準溶液を試 料と同様に操作して得られた検量線より試料中の二酸化 チタン量を求めた。チーズおよびホワイトチョコレート に添加した二酸化チタンの回収率は， $10 \mu \mathrm{g} / \mathrm{g}$ で 92.1$94.9 \%, 10 \mu \mathrm{g} / \mathrm{g}$ で $97.4-99.8 \%$ であった.

なお，本法の定量限界は，試料 $2 \mathrm{~g}$ を用いた場合 5 $\mu \mathrm{g} / \mathrm{g}$ であった.

\section{新刊紹 介}

\section{卵の調理と健康の科学}

\section{佐藤 泰・田名部尚子・中村 良・渡辺乾二共著}

本書は，食形態と健康に重点をおいて解説した䳕卵の 参考書であり，その内容は，(1) 卵の成分と物性，(2) 殻 付卵の品質と眝蔵法, (3) 卵の調理之機能, (4) 卵料理の 活用，(5) 卵製品の活用，(6) 卵の栄養と健康とで構成さ れている，家政学，畜産学，農芸化学における指導書之 してだけではなく，食品工業に携わる技術者，研究者に とって有益な書である。

$16 \times 21.5 \mathrm{~cm}, 284$ 真 1989 年刊,

ISBN 4-87492-055-1 C 3077

弘学出版 4500 円 